\title{
Pengembangan Animasi Virtual Karakter Anak dengan Autisme dengan Model ADDIE
}

\section{(Development of Virtual Character Animation of Children with Autism with the ADDIE Model)}

\author{
Rahadian Kurniawan ${ }^{1}$, Febriana Kurniasari ${ }^{2}$, Restu Rakhmawati ${ }^{3}$
}

\begin{abstract}
The increase in the number of people with autism in Indonesia is followed by an increase in the need of teachers. The main problem related to teaching children with autism is the lack of teaching skills in dealing with children with autism. One of the methods used by prospective teachers of children with autism to improve their teaching skills is by playing role-changing dramas. One person plays the role of a teacher, while the other plays a child with autism. From interviews conducted with several autistic special education students, this method was considered less effective in understanding and responding to children with autism. Nowadays, Virtual Reality (VR) allows prospective teachers to practice improving their teaching skills in a safer environment. Generally, the learning simulation process using VR utilizes virtual humans who have specific features and abilities. This study presents the ADDIE model's use to develop virtual human animation used as a learning agent for prospective teachers of children with autism. The animation represents movements which are often performed by children with autism that can be used as a VR module. From the test results, it is known that the animation developed is considered to represent the behavior of children with autism.
\end{abstract}

Intisari-Kenaikan jumlah penyandang autisme di Indonesia diikuti dengan bertambahnya kebutuhan terhadap pengajar. Permasalahan utama terkait pengajar anak dengan autisme adalah kurangnya keterampilan pengajar dalam menangani anak dengan autisme. Salah satu metode yang digunakan calon pengajar anak dengan autisme untuk meningkatkan keterampilan mengajarnya adalah dengan memainkan drama bertukar peran. Satu orang berperan sebagai guru, sedangkan yang lain berperan sebagai anak dengan autisme. Dari wawancara yang dilakukan terhadap beberapa mahasiswa pendidikan khusus autis, metode tersebut dinilai kurang efektif untuk memahami dan merespons perilaku anak dengan autisme. Dewasa ini, Virtual Reality (VR) memungkinkan calon pengajar berlatih meningkatkan kemampuan mengajarnya pada lingkungan yang lebih aman. Umumnya, proses simulasi pembelajaran menggunakan VR memanfaatkan manusia virtual yang memiliki fitur maupun kemampuan spesifik. Makalah ini menyajikan penggunaan model ADDIE untuk mengembangkan animasi manusia virtual yang dapat digunakan sebagai agen

1,2 Jurusan Informatika, Universitas Islam Indonesia, Jl. Kaliurang km 14 Yogyakarta 55510 (tlp: (0274) 895287 ext 122; fax (0274) 895007 ext 148; e-mail: 'rahadiankurniawan@uii.ac.id, 216523078@students.uii.ac.id)

${ }^{3}$ Program Studi Teknologi Informasi Universitas AMIKOM Yogyakarta, Jl. Padjajaran, Ring Road Utara, Yogyakarta (telp: 0274- 884201-207; fax: 0274-884208; e-mail: resturakhma@amikom.ac.id) pembelajaran bagi calon pengajar anak dengan autisme. Animasi tersebut merupakan representasi gerakan yang sering dilakukan oleh anak dengan autisme yang dapat digunakan sebagai modul pada VR. Dari hasil pengujian yang dilakukan, diketahui bahwa animasi yang dikembangkan dianggap sudah dapat merepresentasikan perilaku anak dengan autisme.

Kata Kunci-Autisme, Animasi, 3D, Gesture, ADDIE.

\section{Pendahuluan}

Jumlah penyandang autisme di Indonesia meningkat cukup pesat setiap tahunnya. Kenaikan jumlah penyandang autisme tersebut diikuti dengan bertambahnya kebutuhan tenaga ahli pengajar anak dengan autisme yang memiliki standar kompetensi guru Pendidikan Luar Biasa (PLB). Terdapat tiga kompetensi guru PLB, seperti kompetensi kepribadian, kompetensi sosial, dan kompetensi profesional [1]. Selain tiga standar kompetensi tersebut, ada persyaratan lainnya yang harus dimiliki, seperti persyaratan psikis atau persyaratan yang memuat kesehatan rohani, dewasa dalam berpikir dan bertindak, mampu mengendalikan emosi, sabar, ramah, bertanggung jawab, dan memiliki jiwa.

Pengajar anak dengan autisme juga memiliki beberapa permasalahan, di antaranya sumber daya manusia dan keterampilan atau keahlian khusus dalam menangani anak dengan autisme yang masih kurang. Pengajar anak dengan autisme harus memiliki tingkat kesabaran yang tinggi karena penanganan anak dengan autisme berbeda dengan anak normal. Tiga tantangan calon pengajar yang sering dilaporkan adalah terkait dengan perilaku lalai dan hiperaktif (34\%), kesulitan memahami dan melakukan tugas (30\%), dan gangguan sosial (26\%) [2].

Sebelum mengemban tugasnya menjadi calon pengajar anak dengan autisme, para calon pengajar anak dengan autisme harus dapat memahami anak dengan autisme tersebut. Sebelum calon pengajar menangani anak dengan autisme secara langsung, para calon pengajar diberikan pengetahuan tentang karakteristik anak dengan autisme dengan cara mengamati video anak dengan autisme atau mengamati anak dengan autisme secara langsung, serta bermain tukar peran guna untuk memahami karakter anak dengan autisme untuk mengetahui cara menangani anak dengan autisme. Namun, menurut calon pengajar anak dengan autisme, hal tersebut dinilai kurang efektif karena calon pengajar baru pertama kali memahami karakteristik anak dengan autisme.

Salah satu teknologi yang dapat membantu adalah virtual reality (VR), yang dapat menjadi simulasi dalam bidang 
pengajaran [3]. Untuk memaksimalkan pengalaman pengguna VR agar lingkungan virtual terlihat lebih nyata, digunakan perangkat keras Head-Mounted Display (HMD). Pembelajaran yang didukung oleh HMD dapat meningkatkan kinerja pembelajaran yang lebih efektif [4]. Akan tetapi, meskipun teknologi VR dapat membantu dalam praktik pembelajaran, hal paling utama dalam pengembangan VR adalah karakter virtual. Penggunaan karakter virtual yang memiliki style dan personalitas yang realistis menunjukkan asosiasi positif terhadap empati pengguna [5]. Menghadirkan sebuah karakter virtual dengan kemampuan spesifik juga memiliki beberapa tantangan, seperti yang dikutip dalam penelitian sebelumnya [6], yang menjelaskan sebuah konsep yang dikenal dengan uncanny valley. Disebutkan bahwa respons seseorang terhadap sesuatu yang mirip manusia (robot, manusia virtual) akan tibatiba bergeser dari empati menjadi jijik saat dianggap gagal mencapai penampilan yang mirip dengan manusia. Untuk mendapatkan karakter virtual yang sesuai dan yang dapat meniru karakteristik anak dengan autisme, perlu dilakukan kajian untuk mengetahui karakteristik umum yang sering dilakukan anak dengan autisme.

Makalah ini dilakukan untuk mencari karakteristik umum anak dengan autisme dengan melalui kajian media, studi literatur, wawancara, dan observasi. Hasil dari kajian dalam makalah ini adalah animasi pemodelan 3D karakter autisme yang dapat diimplentasikan dalam VR untuk membantu calon pengajar berlatih menggunakan VR yang berisi karakteristik anak dengan autisme. Animasi adalah proses teknis yang menghasilkan gerak ilusi dengan mengurutkan gambar diam yang dihasilkan dalam lingkungan analog atau digital secara berurutan. Animasi menjadi salah satu alat yang efektif dalam teknologi informasi di dunia pendidikan baru-baru ini dan sangat dianjurkan untuk meningkatkan pembelajaran individu dengan berkebutuhan khusus [7].

Makalah ini memberikan solusi pada permasalahan calon pengajar anak dengan autisme, yaitu kurangnya keterampilan atau keahlian dalam memahami dan menangani anak dengan autisme [1]. Solusi yang diberikan adalah dengan membuat animasi 3D yang dapat digunakan sebagai modul dalam VR yang berisikan gerakan-gerakan khusus yang sering dilakukan oleh anak dengan autisme. Animasi 3D pada makalah ini merepresentasikan gerakan yang sering dilakukan anak dengan autisme sehingga calon pengajar anak dengan autisme dapat merasakan kesan berinteraksi langsung dengan anak dengan autisme.

\section{Metodologi}

Pada makalah ini digunakan dua tahapan metode, yaitu metode pengumpulan data dan metode pengembangan animasi.

\section{A. Metode Pengumpulan Data}

Untuk mengembangkan pemodelan 3D karakteristik anak dengan autisme perlu digunakan metode pengumpulan data guna mengetahui karakteristik umum anak dengan autisme yang sering dilakukan, yang dijelaskan sebagai berikut.

1) Kajian Media: Kajian media dilakukan dengan cara mengkaji media seperti mengamati video anak dengan autisme di YouTube serta video anak dengan autisme hasil observasi/ kunjungan lapangan.

2) Studi Literatur: Studi ini dilakukan sebagai dasar sebelum mengembangkan penelitian. Studi literatur melakukan review terhadap penelitian-penelitian sebelumnya yang membahas tentang gerakan badan anak dengan autisme, karakteristik anak dengan autisme, kesulitan para calon pengajar, dan contoh media pembelajaran yang baik dalam bidang pendidikan. Literatur-literatur ini berupa jurnal, buku, dan artikel.

3) Wawancara: Wawancara dilakukan kepada pakar untuk mendapatkan karakteristik anak dengan autisme dan kesulitankesulitan calon pengajar anak dengan autisme.

4) Observasi: Observasi dilakukan untuk mengamati lingkungan serta karakteristik umum anak dengan autisme.

\section{B. Metode Pengembangan Animasi}

Untuk mengembangkan animasi anak dengan autisme ini, digunakan model ADDIE dalam proses pembuatannya. Model ADDIE digunakan karena merupakan salah satu model pembelajaran yang memperlihatkan tahapan-tahapan dasar desain sistem pembelajaran yang sederhana, mudah dipelajari, dan dapat memanfaatkan media teknologi [8]. Model ADDIE telah digunakan pada beberapa penelitian sebelumnya untuk mengembangkan teknologi pembelajaran bagi anak dengan autisme [9], [10]. Tahapan-tahapan model ADDIE dijelaskan sebagai berikut.

1) Analisis: Tahapan ini digunakan untuk menganalisis sebuah permasalahan yang ada sebelum dibuatnya sebuah solusi. Masalah pada makalah ini kurangnya pemahaman karakteristik umum anak dengan autisme yang sering dilakukan dalam gerakan badan.

2) Desain: Tahapan desain dilakukan dengan tujuan meneliti metode dan media yang efektif digunakan untuk mencapai tujuan. Tujuan makalah ini adalah mencari tahu karakteristik umum yang sering dilakukan oleh anak dengan autisme yang akan dibuat melalui pemodelan 3D.

3) Development: Tahapan ini mengembangkan tahapan desain, yaitu membuat pemodelan 3D dengan software pengembang animasi 3D.

4) Implementasi: Pada tahapan ini, hasil dari tahapan development diterapkan dalam pembelajaran untuk mengetahui pengaruhnya terhadapa kualitas pembelajaran, sudah efektif atau belum.

5) Evaluasi: Evaluasi merupakan tahapan terakhir dalam model ADDIE. Tahap ini digunakan untuk menilai program pembelajaran yang telah dibuat, sudah sesuai dengan tujuan atau belum. Pada makalah ini dilakukan dua macam evaluasi, yaitu evaluasi formatif dan sumatif. Evaluasi formatif dilakukan untuk mengumpulkan data pada setiap tahapan untuk penyempurnaan. Evaluasi sumatif dilakukan di akhir program untuk mengetahui dampak hasil belajar peserta didik dan kualitas pembelajaran. Dengan menerapkan evaluasi formatif dan sumatif, makalah ini diharapkan menghasilkan keluaran 
yang telah teruji dalam setiap prosesnya dan mengetahui dampak dari produk yang dihasilkan bagi pengajar anak dengan autisme.

\section{HASIL DAN PEMBAHASAN}

\section{A. Metode Pengumpulan Data:}

1) Kajian Media: Kajian media dilakukan dengan cara mengamati dan meneliti video hasil observasi dan beberapa video anak dengan autisme dari YouTube. Video hasil observasi dilakukan di beberapa SLB autisme di Yogyakarta. Pengambilan video observasi dilakukan pada tanggal 12 Maret 2019, 22 Maret 2019, 26 Maret 2019, dan 2 Mei 2019. Isi video hasil observasi tersebut mengamati dan meneliti kegiatan belajar anak dengan autisme yang didampingi oleh pendamping, Video observasi tersebut melibatkan beberapa anak dengan autisme dan dibantu oleh beberapa guru di beberapa SLB khusus autisme di Yogyakarta. Selain video observasi, terdapat pengamatan video anak dengan autisme di YouTube. Pengamatan video di YouTube dilakukan pada bulan Januari dan Februari. Pencarian video anak dengan autisme di YouTube menggunakan kata kunci "autisme Indonesia". Pemilihan video anak dengan autisme dilakukan berdasarkan gerakan badan yang sering dilakukan oleh anak dengan autisme tersebut. Hasil dari kajian media ini adalah daftar-daftar gerakan badan yang sering dilakukan anak dengan autisme.

2) Studi Literatur: Studi literatur dilakukan dengan mengambil beberapa penelitian terkait yang digunakan sebagai acuan dalam mengembangkan makalah ini. Berdasarkan kajian literatur yang telah dilakukan, terdapat 24 literatur yang terpilih dengan menggunakan kata kunci animation, gesture, autisme, 3D, pengajar autisme, dan VR. Proses pencarian literatur dilakukan menlalui Google Scholar dan Science Direct. Pencarian literatur review tersebut dilakukan pada bulan Maret hingga bulan Mei tahun 2019 [11]. Hasil pencarian yang dipilih berdasarkan kriteria seleksi inklusi dan eksklusi yang telah ditentukan adalah sebagai berikut. Literatur yang dipilih harus memenuhi beberapa kriteria seleksi inklusi, di antaranya: literatur membahas tentang autisme; literatur membahas tentang gerakan badan anak dengan autisme; literatur membahas teknologi VR untuk autisme; dan literatur membahas animasi untuk anak dengan autisme. Beberapa literatur tidak dipilih karena mengandung kriteria eksklusif, seperti literatur membahas animasi 2D; literatur membahas perkembangan motorik anak dengan autisme, dan literatur membahas Augmented Reality.

Beberapa penelitian telah membahas mengenai kategori gerakan yang dilakukan oleh anak dengan autisme. Ada tiga macam gerakan yang dilakukan oleh anak dengan autisme, yaitu Social Interaction (SI), Behavior Regulation (BR), dan Joint Attention (JA) [12], [13]. SI adalah gerakan untuk mengarahkan perhatian orang lain ke diri sendiri, misalnya melambaikan tangan; BR adalah gerakan untuk mengontrol perilaku orang lain, misalnya seseorang menunjukkan tangan untuk meminta bantuan diambilkan sesuatu yang tidak terjangkau; sedangkan JA adalah gerakan mengarahkan perhatian orang lain pada sebuah objek, seperti menunjuk pesawat terbang yang lewat. Referensi-referensi [14]-[18] menjelaskan pola komunikasi anak autis dalam menunjukkan sesuatu hal. Anak dengan autisme lebih banyak melakukan gerakan badan dalam menunjukkan sesuatu hal daripada berkomunikasi melalui percakapan. Misalnya, gerakan pointing, gerakan iconic, deictic, metaphoric, emblems [14], ideative, extension, normal, dan pragmatik [15].

Ada dua jenis gerakan gestur, yaitu abstract deictic (gerakan deictic abstrak menunjuk gerakan dalam ruang abstrak misalnya, tangan kanan menunjuk ke sisi kiri meja) dan iconic (digunakan untuk menyerupai objek yang diwakili atau tindakan terkait melalui arah gerakan tangan atau bentuk tangan) [16]. Referensi [17] menemukan sedikit bukti empiris yang membahas bentuk gestur lain, seperti iconic gesture, metaphoric gestures, deictic gestures (gerakan menunjuk), beat gestures (isyarat dengan konten semantik minimal yang diatur dengan prosodi ucapan), emblems (gerakan konvensional seperti tanda "ok"). Referensi [19] menjelaskan bahwa anak dengan autisme sering menggunakan gerakan deictic. Sementarai itu, sebuah penelitian menguji kemampuan anakanak dengan autisme dengan anak Tourette's Disorder (TD) untuk mengetahui yang lebih menghasilkan gerakan badan [20]. Pengamatan juga telah dilakukan terhadap gerakan komunikasi yang sering dilakukan anak dengan autisme [21]. Hasil dari literatur ini menunjukkan bahwa anak dengan autisme sering melakukan request gesture atau gerakan meminta dan pointing gesture atau gerakan menunjuk.

Referensi [22] menjelaskan bahwa ada dua kategori gerakan, yaitu matching gesture, yang menunjukkan kesesuaian gerakan atau ekspresi wajah saat mengamati, menunjuk, dan mengungkapkan objek yang diamati; dan discrepancy gesture, yang menunjuk adanya ketidaksesuaian gerakan atau ekspresi wajah saat mengamati, menunjuk (pointing), dan mengungkapkan objek yang diamati. Pada penelitian lain, dijelaskan bahwa bayi biasa dengan usia 9-13 bulan mulai memberikan isyarat dengan gerakan awal deictic, lalu memasuki tahun kedua dan ketiga mulai muncul gerakan pointing, iconic dan convertional [23]. Hasil dari literatur ini menunjukkan bahwa anak dengan autisme lebih menghasilkan gerakan pointing. Juga telah diteliti bahwa anak dengan autisme lebih sering melakukan gerakan pointing dan showing [24]. Penelitian ini menguji gerakan tubuh anak dengan autisme menggunakan ADOS, yaitu keseluruhan gerakan, isyarat gerakan atau pointing, showing, dan giving.

Berdasarkan kajian literatur pada penelitian-penelitian sebelumnya, sepuluh dari tiga belas studi literatur hanya membahas kategori-kategori gerakan yang dilakukan anak dengan autisme dan tiga dari tiga belas studi literatur hanya membahas anak dengan autisme melakukan gerakan badan dan membandingkan anak dengan autisme dengan anak normal yang banyak melakukan gerakan badan. Berbeda dengan penelitian sebelumnya, makalah ini menyebutkan kategorikategori gerakan anak dengan autisme dan menjelaskan gerakan badan yang sering dilakukan oleh anak dengan autisme, seperti hand flapping, memaju-mundurkan badan, mengepalkan tangan, tangan menepuk meja, dan berjalan jinjit. Dari studi literatur ini didapatkan beberapa gerakan badan yang 
TABEL I

Hasil ANALISIS PENGUMPULAN DATA

\begin{tabular}{|l|l|}
\hline Pengumpulan Data & \multicolumn{1}{|c|}{ Gerakan yang Sering Dilakukan } \\
\hline Kajian media & $\begin{array}{l}\text { Memainkan rambut, memainkan gigi, } \\
\text { berjalan jinjit, berputar, memaju- } \\
\text { mundurkan badan, menepukkan } \\
\text { pergelangan tangan di atas meja, } \\
\text { mengepalkan tangan, melompat-lompat, } \\
\text { membenturkan kepala, memukul dada, } \\
\text { hand flapping. }\end{array}$ \\
\hline Studi literatur & $\begin{array}{l}\text { Menunjuk, melambaikan tangan, } \\
\text { meminta, menepukkan pergelangan } \\
\text { tangan di atas meja, menepukkan jari- } \\
\text { jari tangan di atas meja. }\end{array}$ \\
\hline Wawancara & $\begin{array}{l}\text { Jalan jinjit, memutar badan, memaju- } \\
\text { mundurkan badan, menggaruk dada, } \\
\text { melompat, hand flapping, tepuk tangan. }\end{array}$ \\
\hline Observasi & $\begin{array}{l}\text { Memainkan rambut, melompat, berjalan } \\
\text { jinjit, berputar, memaju-mundurkan } \\
\text { badan, mengetukkan jari-jari di atas } \\
\text { meja, hand flapping, menggoyangkan } \\
\text { kaki. }\end{array}$ \\
\hline
\end{tabular}

sering dilakukan anak dengan autisme, seperti gerakan beat dan gerakan deictic yang disajikan dalam Tabel I.

3) Wawancara: Wawancara dilakukan kepada beberapa pakar, yaitu pakar tumbuh kembang dan kesehatan anak berkebutuhan khusus, pakar pendidikan anak dengan autisme, dan pakar pendidikan inklusif. Wawancara berlangsung pada tanggal 22 Oktober 2019 di Laboratorium Informatika UII. Hasil wawancara tersebut adalah kriteria-kriteria anak dengan autisme, gerakan-gerakan badan yang sering dilakukan anak dengan autisme, dan skema anak dengan autisme. Contoh skema anak dengan autisme adalah sering berjalan dengan kaki jinjit atau memutar-mutarkan badan. Wawancara kedua dilakukan pada tanggal 24 Februari 2020 bersama pakar tumbuh kembang dan kesehatan anak berkebutuhan khusus. Pada wawancara tersebut, dibahas gerakan-gerakan yang sering dilakukan oleh anak dengan autisme berdasarkan daftar gerakan dari hasil pengamatan pada kajian media. Dari wawancara tersebut diperoleh daftar gerakan yang sering dilakukan oleh anak dengan autisme.

4) Observasi: Observasi merupakan kegiatan yang menggunakan pancaindra untuk memperoleh informasi yang diperlukan untuk menjawab masalah penelitian. Observasi dilakukan di salah satu SLB autisme di Yogyakarta yang bernama Dian Amanah. Observasi dilakukan dengan cara mengamati kegiatan yang dilakukan anak dengan autisme selama di sekolah tersebut. Pengamatan tersebut guna mendapatkan gerakan-gerakan badan yang sering dilakukan oleh anak dengan autisme. Selain itu, dilakukan pengamatan terhadap kesulitan-kesulitan pengajar saat menangani anak dengan autisme.

\section{B. Metode Pengembangan Animasi:}

1) Analisis: Berdasarkan hasil pengumpulan data, dilakukan analisis hasil pengumpulan data untuk membangun gerakan animasi yang akan dibuat. Analisis hasil pengumpulan data

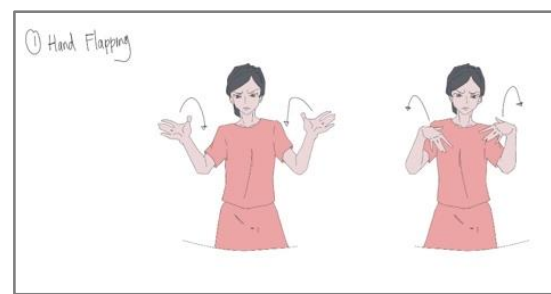

Gbr. 1 Desain gerakan hand flapping.

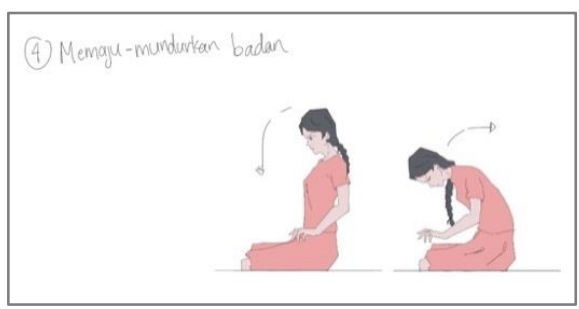

Gbr. 2 Desain gerakan memaju-mundurkan badan

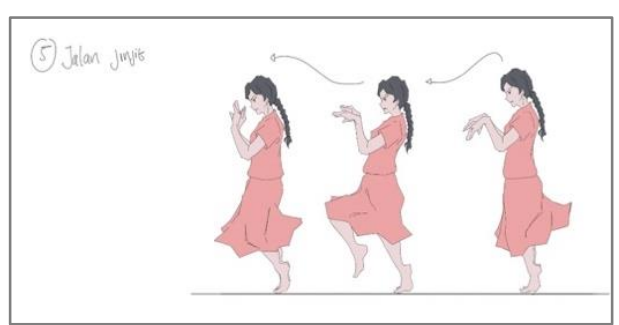

Gbr. 3 Desain gerakan jalan jinjit.

terdiri atas kajian media, studi literatur, wawancara, dan observasi. Analisis hasil pengumpulan data dijelaskan pada Tabel I. Berdasarkan Tabel I, diketahui bahwa terdapat gerakan-gerakan badan yang sering dilakukan oleh anak dengan autisme yang selalu muncul di semua metode pengumpulan data, yakni hand flapping, berjalan jinjit, memaju-mundurkan badan, mengepalkan kedua tangan, dan menepukkan pergelangan tangan di atas meja.

2) Desain: Berdasarkan analisis yang dilakukan sebelumnya, diperoleh karakteristik gestur atau gerakan badan yang sering dilakukan oleh anak dengan autisme. Sebelum proses pembuatan animasi tersebut dilakukan, dibuat sebuah desain dalam bentuk storyboard pembuatan animasi. Gbr. 1 merupakan tampilan desain pada gerakan hand flapping. Gambar sebelah kiri menunjukkan gerakan hand flapping dengan membuka telapak tangan ke arah atas dengan lengan tangan sejajar dengan pundak, sedangkan gambar sebelah kanan menampilkan desain pada gerakan hand flapping dengan mengangkat lengan tangan ke atas hampir sejajar dengan pundak dengan pergelangan tangan ditekuk mengarah ke bawah.

Gbr. 2 menunjukkan desain gerakan memaju-mundurkan badan. Gambar sebelah kiri merupakan posisi awal tampilan desain pada gerakan memaju-mundurkan badan, sedangkan gambar sebelah kanan menunjukkan badan di dorong ke depan kemudian ke belakang hingga punggung menyentuh sandaran kursi. Gbr. 3 merupakan desain gerakan jalan jinjit. Gambar paling kiri menampilkan desain posisi awal gerakan jinjit 


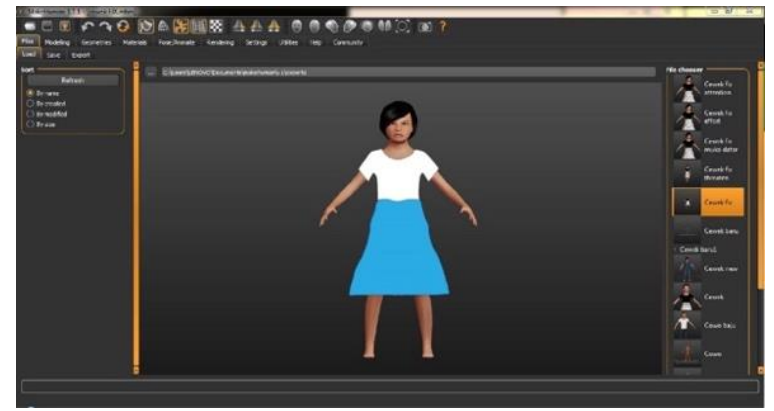

Gbr. 4 Pembuatan karakter di software MakeHuman.

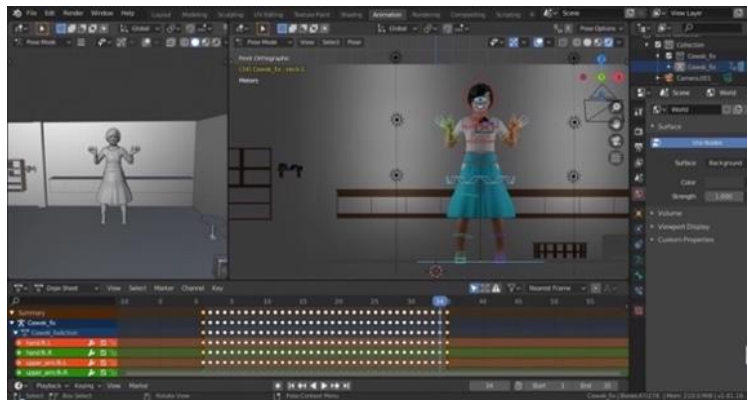

Gbr. 5 Pembuatan animasi di software Blender.

dengan menjinjitkan kaki dan menekuk pergelangan tangan ke arah bawah, gambar tengah merupakan tampilan desain dengan mengangkat kaki sedikit dan kedua tangan pada posisi tengkurap, dan gambar paling kanan merupakan tampilan akhir dengan posisi kaki jinjit dan telapak tangan ke arah atas seperti hand flapping.

3) Development: Tahap development yang dilakukan membuat animasi 3D gerakan badan anak dengan autisme. Untuk membuat gerakan animasi 3D tersebut, dibutuhkan beberapa hardware dan software yang membantu dalam pembuatan animasi 3D.

Hardware yang digunakan dalam pengembangan animasi ini adalah sensor Kinect. Sensor Kinect merupakan perangkat elektronik yang memiliki sensor inframerah dan kamera guna menangkap gerakan user atau objek dalam bentuk 3D. Sensor Kinect dapat dihubungkan ke Blender guna merekam gerakangerakan yang diperagakan oleh user. Dalam makalah ini, sensor Kinect memudahkan pembuatan gerakan-gerakan badan yang rumit dikerjakan secara manual.

Software yang digunakan dalam pengembangan animasi ini adalah MakeHuman dan Blender. MakeHuman merupakan software untuk pemodelan 3D. Model karakter yang dibuat dapat disesuaikan dengan keinginan user. Pada makalah ini, model karakter anak dengan autisme menggunakan karakter anak perempuan berusia 7 tahun. Pembuatan karakter di software MakeHuman ditunjukkan pada Gbr. 4. Blender merupakan software untuk membuat film animasi, pemodelan 3D, aplikasi 3D interaktif, dan permainan video 3D. Blender dapat digunakan untuk membuat gerakan-gerakan yang akan dibuat menggunakan karakter di MakeHuman dengan cara menggerakkan bone-bone secara satu per satu sesuai gerakan yang dibuat. Pembuatan animasi di Blender ditunjukkan pada Gbr. 5.

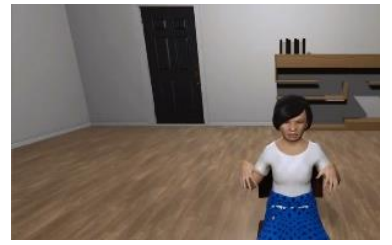

(a)

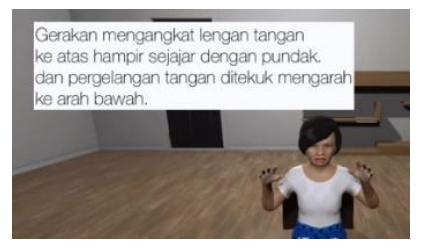

(b)
Gbr. 6 Hand flapping .

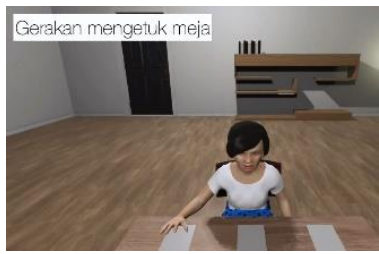

(a)

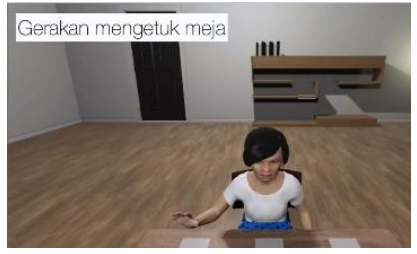

(b)
Gbr. 7 Tangan menepuk meja.

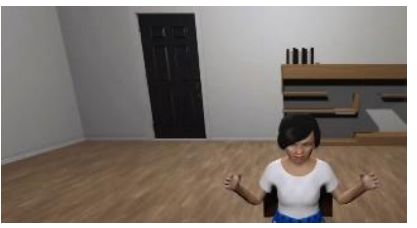

(a)

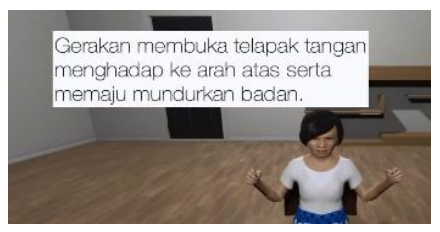

(b)
Gbr. 8 Mengepalkan tangan.

Pada Gbr. 5 terlihat contoh proses pembuatan gerakan badan pada karakter yang sebelumnya dibuat menggunakan MakeHuman. Gerakan dibuat dengan cara menggerakkan bone karakter satu per satu. Pergerakan bone tersebut direkam dalam Blender per frame, yang nantinya dapat di-render menjadi sebuah video animasi.

Hasil pembuatan animasi 3D berupa tampilan video animasi 3D gerakan badan anak dengan autisme dijelaskan sebagai berikut. Hand flapping adalah gerakan mengepak-ngepakkan tangan ke depan dengan lengan tangan sejajar pundak. Hand flapping memiliki beberapa macam gerakan, seperti hand flapping ke depan dan ke samping. Akan tetapi, hasil pengamatan dalam makalah ini adalah hand flapping dengan mengangkat lengan tangan ke atas hampir sejajar pundak.

Gbr. 6(a) merupakan gerakan mengangkat lengan tangan ke atas hampir sejajar pundak dengan pergelangan tangan ditekuk mengarah ke bawah, sedangkan Gbr. 6(b) merupakan gerakan membuka telapak tangan ke arah atas dengan lengan tangan sejajar pundak.

Tangan menepuk meja berupa menekuk pergelangan ke arah atas meja secara bergantian hingga menimbulkan sebuah ritme irama. Gbr. 7(a) merupakan posisi awal animasi sebelum melakukan gerakan menepukkan pergelangan tangan, sedangkan Gbr. 7(b) merupakan gerakan menekuk pergelangan tangan bagian dalam ke arah bawah, kemudian diketukkan ke meja hingga menimbulkan ritme irama.

Mengepalkan tangan merupakan gerakan mengepalkan jarijari tangan secara berulang. Gbr. 8(a) merupakan gerakan tangan membuka telapak tangan menghadap ke arah atas, 


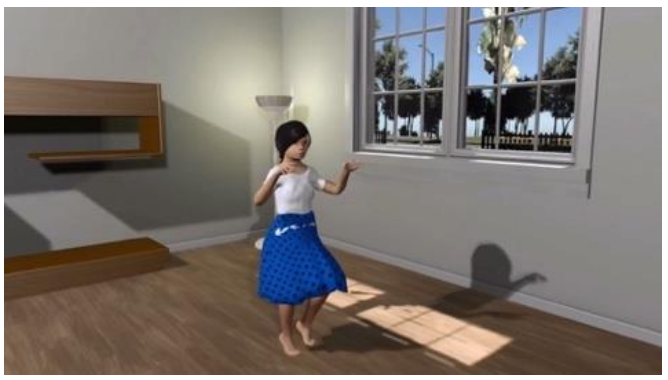

Gbr. 9 Berjalan jinjit.

TABEL II

DAFTAR RESPONDEN

\begin{tabular}{|c|c|c|c|c|}
\hline No. & $\begin{array}{c}\text { Jenis } \\
\text { Kelamin }\end{array}$ & Usia & $\begin{array}{c}\text { Pengalaman } \\
\text { Menangani Anak } \\
\text { dengan Autisme. }\end{array}$ & Kategori \\
\hline 1 & Wanita & 38 tahun & $\begin{array}{c}\text { Mulai bekerja dari } \\
\text { tahun 2008-sekarang }\end{array}$ & Pakar \\
\hline 2 & Wanita & 49 tahun & $\begin{array}{c}\text { Mulai bekerja dari } \\
\text { tahun 2005-sekarang }\end{array}$ & Pakar \\
\hline 3 & Wanita & 58 tahun & $\begin{array}{c}\text { Mulai bekerja dari } \\
\text { tahun 2014-sekarang }\end{array}$ & Guru SLB \\
\hline 4 & Wanita & 48 tahun & $\begin{array}{c}\text { Mulai bekerja dari } \\
\text { tahun 2001-sekarang }\end{array}$ & Guru SLB \\
\hline 5 & Wanita & 25 tahun & $\begin{array}{c}\text { Mulai bekerja dari } \\
\text { tahun 2017-sekarang }\end{array}$ & Guru SLB \\
\hline 6. & Wanita & 35 tahun & $\begin{array}{c}\text { Mulai bekerja dari } \\
\text { tahun 2010-sekarang }\end{array}$ & Guru SLB \\
\hline 7. & Wanita & 50 tahun & $\begin{array}{c}\text { Mulai bekerja dari } \\
\text { tahun 2001-sekarang }\end{array}$ & Guru SLB \\
\hline
\end{tabular}

sedangkan Gbr. 8(b) merupakan gambar tangan mengepal dengan jari-jari tangan mengepal.

Berdasarkan pengumpulan data, gerakan berjalan dengan jinjit sering dilakukan oleh anak dengan autisme. Gerakan jinjit ini dilakukan spontan secara berulang oleh anak dengan autisme pada saat sedang berdiri atau berjalan. Seperti terlihat pada Gbr. 9, gerakan jinjit ini biasanya dikombinasikan dengan gerakan hand flapping.

4) Implementasi: Implementasi dilakukan pada lima orang guru SLB khusus autisme dan dua orang pakar, yaitu pakar pendidik autisme dan pakar tumbuh kembang dan kesehatan anak berkebutuhan khusus. Guru SLB khusus autisme dipilih untuk mendapatkan gambaran karakteristik anak dengan autisme dari pengalaman saat menghadapi anak dengan autisme dan melakukan penilaian terhadap animasi tersebut, sudah sesuai dengan anak dengan autisme atau belum. Sementara itu, pakar dipilih untuk mencari tahu lebih detail secara teori tentang karakteristik anak dengan autisme dan untuk memberikan penilaian terhadap animasi yang dikembangkan, sudah sesuai anak dengan autisme secara teori atau belum. Karakteristik responden yang terlibat pada tahap implementasi dijelaskan pada Tabel II.

5) Evaluasi: Setelah video animasi berhasil dikembangkan, langkah selanjutnya adalah menguji video animasi tersebut kepada pakar anak dengan autisme dan mengisi kuesioner. Pengujian yang dilakukan adalah pengujian animasi dan pengujian kelayakan animasi.

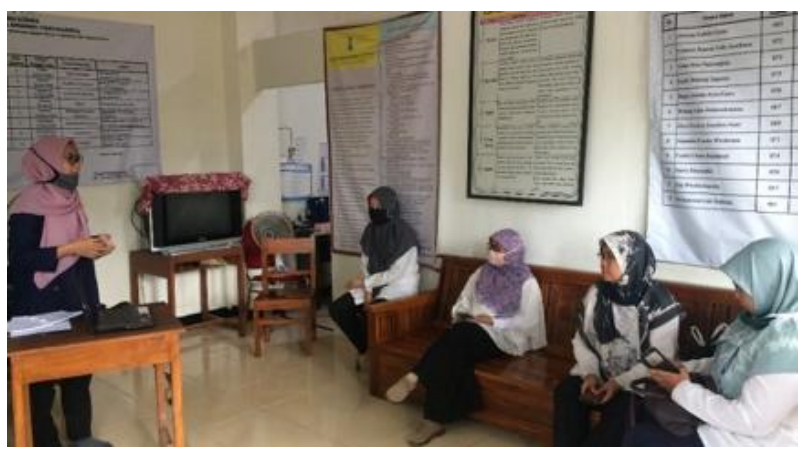

Gbr. 10 Dokumentasi pengujian guru SLB.

TABEL III

DAFTAR PERNYATAAN KUESIONER

\begin{tabular}{|c|l|}
\hline No. & \multicolumn{1}{|c|}{ Pernyataan } \\
\hline 1 & $\begin{array}{l}\text { Animasi ini memudahkan saya dalam memahami gerakan } \\
\text { yang sering dilakukan oleh anak autisme. }\end{array}$ \\
\hline 2 & $\begin{array}{l}\text { Saya menemukan animasi yang memudahkan pekerjaan } \\
\text { saya. }\end{array}$ \\
\hline 3 & Informasi materi yang ada di animasi ini mudah dipahami. \\
\hline 4 & $\begin{array}{l}\text { Materi pada animasi ini sesuai dengan bidang } \\
\text { pembelajaran. }\end{array}$ \\
\hline 5 & $\begin{array}{l}\text { Materi pada animasi ini mudah dipahami oleh calon } \\
\text { pengajar. }\end{array}$ \\
\hline 6 & $\begin{array}{l}\text { Animasi memberikan kemudahan dalam penyampaian } \\
\text { materi ajar. }\end{array}$ \\
\hline 7 & Animasi memiliki tampilan yang nyaman dilihat. \\
\hline 8 & $\begin{array}{l}\text { Animasi ini layak digunakan sebagai media pembelajaran } \\
\text { untuk calon pengajar anak autisme. }\end{array}$ \\
\hline 9 & $\begin{array}{l}\text { Secara keseluruhan, saya terbantu dengan adanya animasi } \\
\text { ini untuk proses pembelajaran. }\end{array}$ \\
\hline
\end{tabular}

Pengujian animasi adalah langkah untuk menguji kelayakan animasi setelah animasi berhasil dikembangkan sesuai dengan tujuan dan untuk menguji kesesuaian animasi sebagai modul pembelajaran. Tujuan dari pengujian ini adalah untuk mengetahui kelayakan animasi yang telah dikembangkan untuk calon pengajar anak dengan autisme. Pengujian dilakukan oleh dua pakar yang menjadi responden. Pengujian animasi dilakukan dengan metode kuesioner. Pada kuesioner tersebut terdapat sembilan pernyataan dan terdapat kritik serta saran. Penyusunan sembilan pernyataan tersebut bertujuan untuk mengukur kelayakan animasi dan kemudahan dalam penyampaian materi animasi. Sembilan pernyataan tersebut dijadikan tolok ukur kelayakan animasi yang dikembangkan untuk dijadikan modul pembelajaran. Gbr. 10 merupakan dokumentasi bersama guru SLB Dian Amanah pada tanggal 1 Juli 2020. Pengujian kelayakan animasi 3D dilakukan dengan menggunakan kuesioner serta melibatkan tujuh orang responden. Tujuh orang responden tersebut terdiri atas lima tenaga pengajar atau guru serta dua pakar. Pengujian ini dibagi menjadi dua, yaitu pengujian terhadap tenaga pengajar dan pengujian terhadap pakar. Daftar pernyataan yang terdapat pada kuesioner disajikan pada Tabel III.

Setelah membagikan lembar kuesioner kepada pakar, tahap selanjutnya adalah melakukan proses analisis terhadap kuesioner yang telah diisi. Hasil pengujian pernyataan pertama disajikan pada Tabel IV. Pada pengujian ini, nilai Likert 
TABEL IV

Hasil Pengujian PeRnyataAn Pertama

\begin{tabular}{|c|c|l|c|c|c|}
\hline $\begin{array}{c}\text { Pernya- } \\
\text { taan }\end{array}$ & No & Keterangan & Skala & $\begin{array}{c}\text { Respon- } \\
\text { den }\end{array}$ & $\begin{array}{c}\text { Skala* } \\
\text { Responden }\end{array}$ \\
\hline \multirow{6}{*}{1} & 1 & Sangat setuju & 5 & 1 & 5 \\
\cline { 2 - 6 } & 2 & Setuju & 4 & 1 & 4 \\
\cline { 2 - 6 } & 3 & Netral & 3 & 0 & 0 \\
\cline { 2 - 6 } & 4 & Tidak setuju & 2 & 0 & 0 \\
\cline { 2 - 6 } & 5 & $\begin{array}{l}\text { Sangat tidak } \\
\text { setuju }\end{array}$ & 1 & 0 & 0 \\
\hline \multicolumn{3}{|l|}{ Total } & 2 & 9 \\
\hline
\end{tabular}

TABEL V

Hasil PERSENTASE KeSELURUhan PERnyataAN

\begin{tabular}{|c|l|c|c|}
\hline No. & \multicolumn{1}{|c|}{ Pernyataan } & Persentase & Nilai \\
\hline 1 & $\begin{array}{l}\text { Animasi ini memudahkan saya } \\
\text { dalam memahami gerakan yang } \\
\text { sering dilakukan oleh anak autisme. }\end{array}$ & $90 \%$ & $\begin{array}{l}\text { Sangat } \\
\text { setuju }\end{array}$ \\
\hline 2 & $\begin{array}{l}\text { Saya menemukan animasi yang } \\
\text { memudahkan pekerjaan saya. }\end{array}$ & $80 \%$ & $\begin{array}{l}\text { Sangat } \\
\text { setuju }\end{array}$ \\
\hline 3 & $\begin{array}{l}\text { Informasi materi yang ada di } \\
\text { animasi ini mudah dipahami. }\end{array}$ & $\begin{array}{l}\text { Sangat } \\
\text { setuju }\end{array}$ \\
\hline 4 & $\begin{array}{l}\text { Materi pada animasi ini sesuai } \\
\text { dengan bidang pembelajaran. }\end{array}$ & $\begin{array}{l}\text { Sangat } \\
\text { setuju }\end{array}$ \\
\hline 5 & $\begin{array}{l}\text { Materi pada animasi ini mudah } \\
\text { dipahami oleh calon pengajar. }\end{array}$ & $\begin{array}{l}\text { Sangat } \\
\text { setuju }\end{array}$ \\
\hline 6 & $\begin{array}{l}\text { Animasi memberikan kemudahan } \\
\text { dalam penyampaian materi ajar. }\end{array}$ & $\begin{array}{l}\text { Sangat } \\
\text { setuju }\end{array}$ \\
\hline 7 & $\begin{array}{l}\text { Animasi memiliki tampilan yang } \\
\text { nyaman dilihat. }\end{array}$ & $\begin{array}{l}\text { Sangat } \\
\text { setuju }\end{array}$ \\
\hline 8 & $\begin{array}{l}\text { Animasi ini layak digunakan sebagai } \\
\text { media pembelajaran untuk calon } \\
\text { pengajar anak autisme. }\end{array}$ & $\begin{array}{l}\text { Sangat } \\
\text { setuju }\end{array}$ \\
\hline 9 & $\begin{array}{l}\text { Secara keseluruhan, saya terbantu } \\
\text { dengan adanya animasi ini untuk } \\
\text { proses pembelajaran. }\end{array}$ & $\begin{array}{l}\text { Sangat } \\
\text { setuju }\end{array}$ \\
\hline
\end{tabular}

tertinggi adalah 5 dan jumlah responden adalah dua, sehingga dengan menggunakan (1), dapat diperoleh skor ideal.

$$
\begin{aligned}
\text { skor ideal } & =\text { nilai Likert tertinggi } \times \text { jumlah responden }(1) \\
& =5 \times 5 \\
& =25 .
\end{aligned}
$$

Dengan menggunakan (2), dapat dihitung persentase pernyataan pertama.

$$
\begin{aligned}
Y & =\frac{X}{\text { skor ideal }} \times 100 \% \\
& =\frac{9}{10} \times 100 \% \\
& =90 \% .
\end{aligned}
$$

Perhitungan persentase kedua hingga kesembilan juga dilakukan dengan cara yang sama. Hasil perhitungan persentase setiap pernyataan kuesioner diperlihatkan pada Tabel V dan Gbr. 11. Berdasarkan pemaparan pada Tabel V dan Gbr. 11, penilaian terendah terdapat pada pernyataan kedua, keempat, dan kelima, sehingga diharapkan animasi dapat dikembangkan lagi agar dapat lebih sesuai dengan materi pembelajaran,

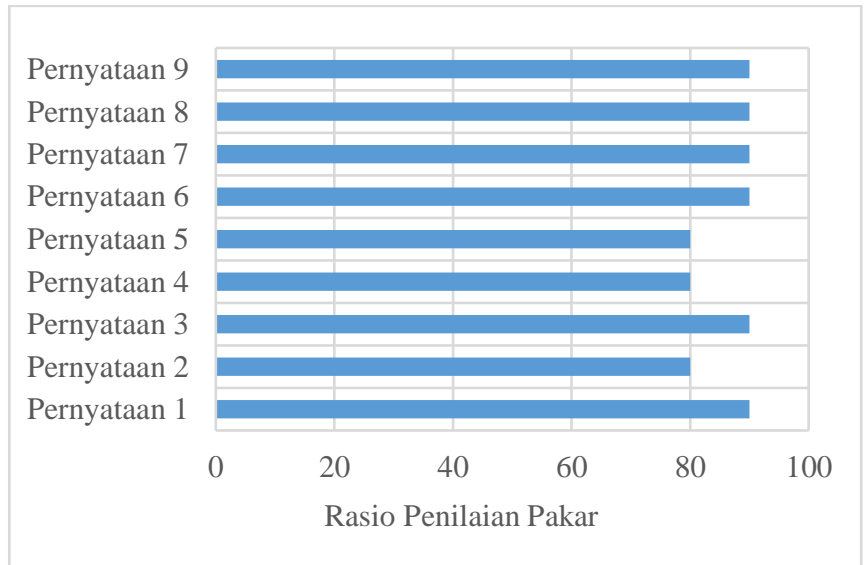

Gbr. 11 Grafik indeks pakar.

TABEL VI

Hasil PEngujian PeRnyataAn Pertama

\begin{tabular}{|c|c|l|c|c|c|}
\hline $\begin{array}{c}\text { Pernya- } \\
\text { taan }\end{array}$ & No. & Keterangan & Skala & Responden & $\begin{array}{c}\text { Skala * } \\
\text { Responden }\end{array}$ \\
\hline \multirow{4}{*}{1} & 1 & Sangat Setuju & 5 & 1 & 5 \\
\cline { 2 - 6 } & 2 & Setuju & 4 & 4 & 16 \\
\cline { 2 - 6 } & 3 & Netral & 3 & 0 & 0 \\
\cline { 2 - 6 } & 4 & Tidak Setuju & 2 & 0 & 0 \\
\cline { 2 - 6 } & 5 & $\begin{array}{l}\text { Sangat Tidak } \\
\text { Setuju }\end{array}$ & 1 & 0 & 0 \\
\hline \multicolumn{2}{|c|}{ Total } & 5 & 21 \\
\hline
\end{tabular}

mempermudah pekerjaan responden, dan lebih mudah dipahami.

Selain penilaian yang dilakukan menggunakan kuesioner, terdapat beberapa kritik dan saran dari pakar sebagai berikut.

- Diperlukan penyesuaian pada beberapa gerakan animasi agar terlihat lebih nyata. Misalnya, pada gerakan animasi mengepalkan tangan, tangan kurang mengepal.

- Ada beberapa gerakan yang dapat dikombinasikan karena ada juga gerakan anak yang berupa kombinasi beberapa gerakan. Misalnya, hand flapping dengan stimming atau gerakan lainnya.

- Jika ada calon pengajar yang tunarungu, perlu ada tulisan naratif, sedangkan untuk tunanetra, dapat dikembangkan pesan suara, karena ada mahasiswa calon pengajar PLB yang juga memiliki disabilitas.

Pengujian selanjutnya merupakan pengujian terhadap tenaga pengajar/guru SLB khusus autisme. Terhadap hasil lembar kuesioner yang telah dibagikan, dilakukan proses analisis. Hasil analisis kuesioner ditunjukkan pada Tabel VI.

Pada pengujian ini, nilai Likert tertinggi adalah 5 dan jumlah responden adalah lima, sehingga dengan menggunakan (1), diperoleh skor ideal sebagai berikut.

$$
\text { skor ideal }=5 \times 5=25 \text {. }
$$

Dengan menggunakan (2), nilai persentase pernyataan pertama adalah sebagai berikut.

$$
Y=\frac{21}{25} \times 100 \%=84 \% \text {. }
$$




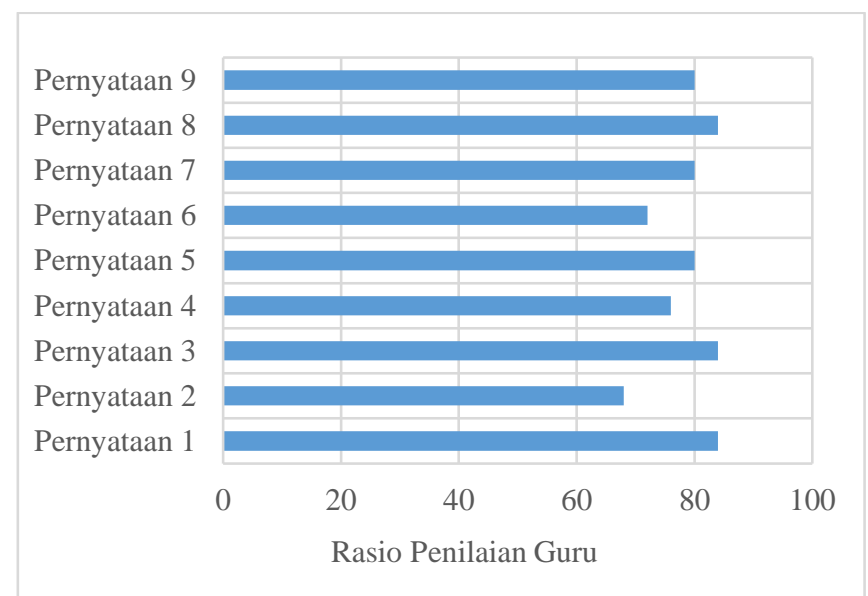

Gbr. 12 Grafik indeks guru.

TABEL VII

Hasil Persentase Keseluruhan PernyataAn

\begin{tabular}{|c|l|c|l|}
\hline No & \multicolumn{1}{|c|}{ Pernyataan } & Persentase & Nilai \\
\hline 1 & $\begin{array}{l}\text { Animasi ini memudahkan saya } \\
\text { dalam memahami gerakan yang } \\
\text { sering dilakukan oleh anak } \\
\text { autisme. }\end{array}$ & $84 \%$ & $\begin{array}{l}\text { Sangat } \\
\text { setuju }\end{array}$ \\
\hline 2 & $\begin{array}{l}\text { Saya menemukan animasi yang } \\
\text { memudahkan pekerjaan saya. }\end{array}$ & $68 \%$ & Setuju \\
\hline 3 & $\begin{array}{l}\text { Informasi materi yang ada di } \\
\text { animasi ini mudah dipahami. }\end{array}$ & $84 \%$ & $\begin{array}{l}\text { Sangat } \\
\text { setuju }\end{array}$ \\
\hline 4 & $\begin{array}{l}\text { Materi pada animasi ini sesuai } \\
\text { dengan bidang pembelajaran. }\end{array}$ & $76 \%$ & Setuju \\
\hline 5 & $\begin{array}{l}\text { Materi pada animasi ini mudah } \\
\text { dipahami oleh calon pengajar. }\end{array}$ & $80 \%$ & $\begin{array}{l}\text { Sangat } \\
\text { setuju }\end{array}$ \\
\hline 6 & $\begin{array}{l}\text { Animasi memberikan kemudahan } \\
\text { dalam penyampaian materi ajar. }\end{array}$ & $72 \%$ & Setuju \\
\hline 7 & $\begin{array}{l}\text { Animasi memiliki tampilan yang } \\
\text { nyaman dilihat. }\end{array}$ & $80 \%$ & $\begin{array}{l}\text { Sangat } \\
\text { setuju }\end{array}$ \\
\hline 8 & $\begin{array}{l}\text { Animasi ini layak digunakan } \\
\text { sebagai media pembelajaran untuk } \\
\text { calon pengajar anak autisme. }\end{array}$ & $84 \%$ & $\begin{array}{l}\text { Sangat } \\
\text { setuju }\end{array}$ \\
\hline 9 & $\begin{array}{l}\text { Secara keseluruhan, saya terbantu } \\
\text { dengan adanya animasi ini untuk } \\
\text { proses pembelajaran. }\end{array}$ & $80 \%$ & $\begin{array}{l}\text { Sangat } \\
\text { setuju }\end{array}$ \\
\hline
\end{tabular}

Perhitungan persentase kedua hingga kesembilan juga dilakukan dengan cara yang sama. Hasil perhitungan persentase untuk setiap pernyataan kuesioner ditunjukkan pada Tabel VII dan Gbr. 12.

Berdasarkan pemaparan pada Tabel VII, penilaian terendah terdapat pada pernyataan kedua sehingga diharapkan nantinya animasi dapat dikembangkan lagi agar mampu mempermudah pekerjaan responden. Selain penilaian yang dilakukan menggunakan kuesioner, terdapat beberapa kritik dan saran dari pakar yaitu sebagai berikut.

- Animasi sudah sesuai dengan gerakan siswa autisme.

- Animasi bisa melengkapi gerakan yang muncul saat emosi tidak stabil.
- Perlu ditambahkan lagi gerakan badan yang dimiliki oleh anak dengan autisme atau karakter, karena gerakan badan anak dengan autisme sangat banyak.

- Animasi cukup bagus dan mungkin dapat diperbaiki lagi pada ritme gerakannya, karena anak dengan autisme melakukan gerakan berulang tersebut terkait dengan emosinya. Misalnya, saat marah atau tantrum ritmenya menjadi cepat dan saat santai atau biasa gerakannya santai juga.

- Dapat ditambahkan deskripsi tentang perilaku tersebut terjadi ketika sedang stabil dan emosi. Jadi, kecepatan gerakan dapat dikurangi atau ditambah.

- Dapat ditambahkan gerakan-gerakan yang lebih detail lagi. Misalnya, gerakan kedua lengan ditekuk di samping disertai gerakan kepala maju-mundur.

\section{KESIMPULAN}

Dari hasil pengembangkan animasi pada makalah ini dan hasil pengujian animasi kepada pakar dan guru SLB khusus autisme, dapat diambil kesimpulan sebagai berikut. Animasi gerakan badan anak dengan autisme dibangun menggunakan software MakeHuman dan Blender yang menghasilkan gerakan jalan jinjit, hand flapping, memaju-mundurkan badan, tangan menepuk meja, dan mengepalkan tangan. Gerakan yang dibangun disesuaikan dengan kebutuhan pembelajaran bagi calon pengajar anak dengan autisme berdasarkan hasil wawancara terhadap pakar pembelajaran anak dengan autisme tentang gerakan badan yang sering dilakukan oleh anak dengan autisme. Berdasarkan hasil pengujian terhadap pakar dan guru khusus SLB autisme, dapat disimpulkan bahwa animasi yang dikembangkan sudah sesuai dengan karakteristik anak dengan autisme dan animasi tersebut layak digunakan sebagai media pembelajaran bagi calon pengajar anak dengan autisme. Berdasarkan kesimpulan tersebut, terdapat beberapa hal yang dapat dikembangkan pada penelitian selanjutnya. Saran untuk pengembangan penelitian selanjutnya di antaranya sebagai berikut. Gerakan-gerakan badan dapat dikembangkan menjadi kombinasi gerakan badan untuk menciptakan gerakan yang lebih natural. Animasi gerakan badan juga dapat dikembangkan dengan menambahkan suara deskripsi gerakan badan dalam video animasi untuk calon pengajar yang memiliki disabilitas.

\section{UCAPAN TERIMA KASIH}

Penelitian ini didukung dan didanai oleh Hibah Penelitian Tesis Magister DIKTI dengan kontrak No: 111/SP2H/LT/DRPM/2019.

\section{REFERENSI}

[1] D. Nahampun, "Kompetensi Kepribadian Guru dalam Pelaksanaan Pembelajaran Anak Autis di SLB C Karya Bhakti," J. Widia Ortodidaktika, Vol. 6, No. 5, hal. 538-546, 2017.

[2] I. Obrusnikova dan S.R. Dillon, "Challenging Situations when Teaching Children with Autism Spectrum Disorders in General Physical Education," Adapt. Phys. Act. Q., Vol. 28, No. 2, hal. 113-131, 2011.

[3] D.H. Fudholi, R. Kurniawan, D.P.E. Jalaputra, dan I. Muhimmah, "Development of Virtual Reality Applications with the ADDIE Model for Prospective Educators of Children with Autism," J. RESTI (Rekayasa Sist. dan Teknol. Informasi), Vol. 4, No. 4, hal. 672-681, 2020. 
[4] B. Wu, X. Yu, dan X. Gu, "Effectiveness of Immersive Virtual Reality Using Head-Mounted Displays on Learning Performance: A MetaAnalysis," Br. J. Educ. Technol., Vol. 51, No. 6, hal. 1991-2005, 2020.

[5] K. Zibrek, E. Kokkinara, dan R. Mcdonnell, "The Effect of Realistic Appearance of Virtual Characters inImmersive Environments - Does the Character's Personality Play aRole?," IEEE Trans. Vis. Comput. Graph., Vol. 24, No. 4, hal. 1681-1690, 2018.

[6] M. Mori, K.F. MacDorman, dan N. Kageki, "The Uncanny Valley," IEEE Robot. Autom. Mag., Vol. 19, No. 2, hal. 98-100, 2012.

[7] B. Baglama, Y. Yucesoy, dan A. Yikmis, "Using Animation as a Means of Enhancing Learning of Individuals with Special Needs," TEM J., Vol. 7, No. 3, hal. 670-677, 2018.

[8] J. Jeuring, R. van Rooij, dan N. Pronost, "The 5/10 Method: A Method for Designing Educational Games," dalam Games and Learning Alliance, Vol. 8605, A. De Gloria, Ed. Cham, Switzerland: Springer, 2014, hal. 364-369.

[9] R. Kurniawan, R. Rakhmawati, I. Muhimmah, dan D.P.E. Jalaputra, "Desain Kerangka Kerja Permainan Digital Sebagai Media Terapi Kemampuan Sosial Anak Autis," J. Nas. Tek. Elektro dan Teknol. Inf., Vol. 8, No. 3, hal. 225-234, 2019.

[10] D.H. Fudholi, R. Kurniawan, D.P.E. Jalaputra, dan I. Muhimmah, "Pengembangan Aplikasi Virtual Reality dengan Model ADDIE untuk Calon Tenaga Pendidik Anak dengan Autisme," J. Resti (Rekayasa Sist. dan Teknol. Informasi), Vol. 4, No. 4, hal. 672-681, 2020.

[11] F. Kurniasari dan R. Kurniawan, "Animasi Pembelajaran Gesture atau Gerakan Badan pada Anak dengan Autisme," Seminar Nasional Informatika Medis (SNIMed), 2019, No. 3, hal. 28-33.

[12] L.R. Watson, E.R. Crais, G.T. Baranek, J.R. Dykstra, dan K.P. Wilson, "Communicative Gesture Use in Infants With and Without Autism: A Retrospective Home Video Study," Am. J. Speech-Language Pathol., Vol. 22, No. 1, hal. 25-39, 2013.

[13] S.E. Colgan, E. Lanter, C. McComish, L.R. Watson, E.R. Crais, dan G.T Baranek, "Analysis of Social Interaction Gestures in Infants with Autism," Child Neuropsychol., Vol. 12, No. 4-5, hal. 307-319, 2006.

[14] M.B. Bakan, "The Musicality of Stimming: Promoting Neurodiversity in the Ethnomusicology of Autism," MUSICultures, Vol. 41, No. 2, hal. 133-161, 2014.
[15] M. Mastrogiuseppe, O. Capirci, S. Cuva, dan P. Venuti, "Gestural Communication in Children with Autism Spectrum Disorders During Mother-Child Interaction," Autism, Vol. 19, No. 4, hal. 469-481, 2015.

[16] W.-C. So, M. Lui, T.-K. Wong, dan L.-T. Sit, "The Use of Hand Gestures to Communicate About Nonpresent Objects in Mind Among Children with Autism Spectrum Disorder," J. Speech, Lang. Hear. Res., Vol. 58, No. 2, hal. 373-382, 2015.

[17] A. de Marchena dan I.M. Eigsti, "Conversational Gestures in Autism Spectrum Disorders: Asynchrony but Not Decreased Frequency," Autism Res., Vol. 3, No. 6, hal. 311-322, 2010.

[18] B.A. Braddock, C. Gabany, M. Shah, E.S. Armbrecht, dan K.A. Twyman, "Patterns of Gesture Use in Adolescents with Autism Spectrum Disorder," Am. J. Speech-Language Pathol., Vol. 25, No. 3, hal. 408-415, 2016.

[19] B. Choi, P. Shah, M.L. Rowe, C.A. Nelson, dan H. Tager-Flusberg, "Gesture Development, Caregiver Responsiveness, and Language and Diagnostic Outcomes in Infants at High and Low Risk for Autism," $J$. Autism Dev. Disord., Vol. 50, No. 7, hal. 2556-2572, 2020.

[20] L. Camaioni, P. Perucchini, F. Muratori, B. Parrini, dan A. Cesari, "The Communicative Use of Pointing in Autism: Developmental Profile and Factors Related to Change," Eur. Psychiatry, Vol. 18, No. 1, hal. 6-12, 2003.

[21] L. Camaioni, P. Perucchini, F. Muratori, dan A. Milone, "Brief Report: A Longitudinal Examination of the Communicative Gestures Deficit in Young Children with Autism," J. Autism Dev. Disord., Vol. 27, No. 6, hal. 715-725, 1997.

[22] S. Mustafa, T. Nusantara, S. Subanji, dan S. Irawati, "Karakterisasi Gerak Tubuh Penyandang Autis dalam Mengidentifikasi Bangun Ruang," J. Ilmu Pendidik., Vol. 22, No. 1, hal. 63-73, 2017.

[23] E.S. Lebarton dan J.M. Iverson, "Gesture Development in Toddlers with an Older Sibling with Autism," Int. J. Lang. Commun. Disord., Vol. 51, No. 1, hal. 18-30, 2016.

[24] S.S. Manwaring, D.L. Mead, L. Swineford, dan A. Thurm, "Modelling Gesture Use and Early Language Development in Autism Spectrum Disorder," Int. J. Lang. Commun. Disord., Vol. 52, No. 5, hal. 637-651, 2017. 